\title{
The Advocate
}

Volume 23

Number 2 Spring - Summer 2016

Article 7

4-1-2016

\section{An Examination of External Influences and Internal Issues Challenging Teacher Education Today}

Jill Gonzalez-Bravo

MidAmerica Nazarene University

Donna Augustine-Shaw

Kansas State University

Follow this and additional works at: https://newprairiepress.org/advocate

Part of the Teacher Education and Professional Development Commons

\section{Recommended Citation}

Gonzalez-Bravo, Jill and Augustine-Shaw, Donna (2016) "An Examination of External Influences and Internal Issues Challenging Teacher Education Today," The Advocate: Vol. 23: No. 2. https://doi.org/ 10.4148/2637-4552.1038

This Research Article is brought to you for free and open access by New Prairie Press. It has been accepted for inclusion in The Advocate by an authorized administrator of New Prairie Press. For more information, please contact cads@k-state.edu. 


\title{
An Examination of External Influences and Internal Issues Challenging Teacher Education Today
}

\author{
Abstract \\ Today's educators are not solely content experts, but reflective practitioners competent in theory and \\ complex learning processes. They are obligated to construct classrooms to meet the diverse needs of \\ each child within a culture of global competition and increased levels of accountability. Prior studies \\ amplify a necessary focus on preparing teachers capable of meeting the needs of each student from day \\ one on the job. However, a myriad of obstacles facing teacher preparation identified throughout research \\ provide clear direction for additional attention. The following is an investigation of external influences and \\ internal issues that challenged the current model of teacher preparation programs. Insights may serve to \\ inform teacher educator research and support programs in the professional development of future \\ teachers. \\ Historically teacher education programs have undergone sharp criticisms in regards to their influence on \\ teacher effectiveness (Book \& Freeman, 1986; Cochran-Smith \& Zeichner, 2005; Cole \& Knowles, 1993; \\ Hollingsworth, 1989; Holt-Reynolds, 1992; Reynolds, Ross, \& Rakow, 2002; Weinstein, 1990; Zeichner \& \\ Tabachnick, 1981). However, many researchers recognized the central role preparation programs played \\ in equipping effective educators with important entry-level knowledge and skills (Boyd, Grossman, Loyd, \& \\ Wyckoff, 2009; Darling-Hammond \& Bransford, 2005, Fullan \& Stiegelbauer, 2007; Hamilton \& Pinnegar, \\ 2001; Korthagen, 2004; RESPECT, 2012; Sprinthall, Reiman, \& TheisSprinthall, 1996; Wilson, 2009). \\ Interestingly, Cochran-Smith (2003) recognized that "teacher educators - those who teach the teachers - \\ are now the linchpins in educational reforms of all kinds" (p. 5). Despite these noted accolades, the \\ myriad of identified obstacles noted throughout research on the effectiveness of preparation programs \\ warrants investigation. The following article highlights discussion of the external global and national \\ influences and internal program issues that challenge the practice of teacher educators (TE) and the \\ preparation of teacher candidates (TC).
}




\title{
An Examination of External Influences and Internal Issues Challenging Teacher Education Today
}

\author{
Jill Gonzalez-Bravo \\ MidAmerica Nazarene University \\ Donna Augustine-Shaw \\ Kansas State University
}

\begin{abstract}
Today's educators are not solely content experts, but reflective practitioners competent in theory and complex learning processes. They are obligated to construct classrooms to meet the diverse needs of each child within a culture of global competition and increased levels of accountability. Prior studies amplify a necessary focus on preparing teachers capable of meeting the needs of each student from day one on the job. However, a myriad of obstacles facing teacher preparation identified throughout research provide clear direction for additional attention. The following is an investigation of external influences and internal issues that challenged the current model of teacher preparation programs. Insights may serve to inform teacher educator research and support programs in the professional development of future teachers.

Historically teacher education programs have undergone sharp criticisms in regards to their influence on teacher effectiveness (Book \& Freeman, 1986; Cochran-Smith \& Zeichner, 2005; Cole \& Knowles, 1993; Hollingsworth, 1989; Holt-Reynolds, 1992; Reynolds, Ross, \& Rakow, 2002; Weinstein, 1990; Zeichner \& Tabachnick, 1981). However, many researchers recognized the central role preparation programs played in equipping effective educators with important entry-level knowledge and skills (Boyd, Grossman, Loyd, \& Wyckoff, 2009; Darling-Hammond \& Bransford, 2005, Fullan \& Stiegelbauer, 2007; Hamilton \& Pinnegar, 2001; Korthagen, 2004; RESPECT, 2012; Sprinthall, Reiman, \& Theis-Sprinthall, 1996; Wilson, 2009). Interestingly, Cochran-Smith (2003) recognized that "teacher educators-those who teach the teachers-are now the linchpins in educational reforms of all kinds" (p. 5). Despite these noted accolades, the myriad of identified obstacles noted throughout research on the effectiveness of preparation programs warrants investigation. The following article highlights discussion of the external global and national influences and internal program issues that challenge the practice of teacher educators (TE) and the preparation of teacher candidates (TC).
\end{abstract}




\section{Global Issues Impacting Teacher Education}

Innovation and technology have prompted an overall shift in norms throughout the education world. Marzano and Heflebower (2012) in Teaching and Assessing $21^{\text {st }}$ Century Skills provided a historical glimpse of the impact of technology on America's jobs. A shift from "manufacturing and industrial jobs to service-sector occupations" altered the needed skill sets for America's future workforce (p. 4). Two categories of skills required for the $21^{\text {st }}$ century were identified, cognitive and conative. Cognitive skills, first made famous in 1956 by Benjamin Bloom, are likely familiar to those in the education world-however conative skills have more recently become the focus of $21^{\text {st }}$ century skill development. Conative skills support collaboration and focus on an ability to synthesize knowledge and feelings to assess appropriate responses to situations.

Technology not only altered technical, analytical, and emotional skills but resulted in the "death of distance" (Zhao, 2011, p. 422). Technology decreased borders and increased issues surrounding globalization. Zhao (2011) highlighted five challenges to teacher education that were influenced by technology-induced globalization. First, Zhao (2010) recognized that educators must equip students for competition in a job market that extends beyond national borders. President Obama (2009) discussed this increased competition in a speech given to the Hispanic Chamber of Commerce.

This has never been truer than it is today. In a 21st-century world where jobs can be shipped wherever there's an Internet connection, where a child born in Dallas is now competing with a child in New Delhi, where your best job qualification is not what you do, but what you know ...education is no longer just a pathway to opportunity and success, it's a prerequisite for success. (para. 7)

As a result of globalization, Zhao (2010) postulated additional impact and relevance to teacher education. Zhao's (2010) second premise recognized that globalization shifted from what was once local and national accreditation to "increased pressure to be judged on a global stage" (p. 425). Zhao's (2010) third premise addressed the dramatic increase of migration and the resultant diversity within U.S. classrooms. He stated that in America (2010), 20\% of children ages five to 17 had a foreign-born parent. Gollnick and Chinn (2006) estimated that by the year 2026, 15 million English Language Learners would enroll in public schools and would require teachers able to ensure the right of each child to continue to learn grade level content while learning English.

Zhao's (2010) fourth premise focused on an educator's ability to improve student's cultural and linguistic knowledge. The age of globalization left little room for ethnocentrism however within American schools, there remained limited emphasis on 
multiculturalism and second language acquisition (Zhao, 2010). The majority of educators were themselves monolingual (Brookhart \& Freeman, 1992). Lastly, Zhao stated that future teachers must be prepared to instill within future students their role as "global citizens" (Zhao, 2010, p. 426).

These five challenges present a dilemma to teacher education preparation, reflective of the need for teachers to shift instructional methodologies to meet $21^{\text {st }}$ century skill development for every student. On the same stage, additional responsibility is placed on teacher education programs to train educators to meet the diverse learning needs of each student (Klecka, Lin, Odell, Spalding, \& Wang, 2010). Such demands have resulted in a variety of national issues impacting teaching and teacher preparation.

\section{National Issues Impacting Teacher Education}

America has responded to technology-induced globalization and increased competition to reform mandates (No Child Left Behind Act, 2001), national standards (Common Core Standards, 2010), and program proposals (RESPECT, 2012) that influence teacher preparation. President George W. Bush's administration (2001-2009) emphasized educational reform by drafting the No Child Left Behind Act (NCLB, 2001). This standards-based movement increased school accountability by mandating annual assessments of student academic progress and increased teacher qualification requirements. While the NCLB lost momentum due to pending Congressional re-authorization, national standards that incorporated higher-level thinking and problem-solving skills have emerged, such as the Common Core Standards (2010) and Next Generation Science Standards (2013). To ensure student success, the Obama Administration (2009-now) proposed the Recognizing Educational Success, Professional Excellence and Collaborative Teaching (RESPECT) program (2012). Several components of this program directly addressed reform within teacher education programs. Opening statements made by Secretary of Education, Arne Duncan, at the Second International Summit on the Teaching Profession (2012) supported such reforms and identified teacher education programs as doing "at best a mediocre job of preparing teachers and school leaders" (para. 37).

While those in leadership may label teacher education as "the worst problem" in educational reform efforts (Fullan \& Stiegelbauer, 2007, p. 278), preparation programs were often noted as an "afterthought" in education reform and funding efforts (p. 278). With the exception of mathematics and science instruction, funding to support teacher education was recognized as "extremely limited" (Zeichner, 2005, p. 751). Funding disparities challenge the more recent teacher preparation reform efforts. 
Two national accrediting bodies for teacher education merged to form the Council for the Accreditation of Educator Preparation (CAEP). The CAEP (2013) standards arose from this union and have attempted to reconcile concerns. These far-reaching standards increased requirements for entrance into teacher education programs and required multiple measures to document teacher education program effectiveness.-Requirements for high quality educational outcomes as proposed by CAEP national initiatives defined and drove focus on exemplary teacher education preparation. Guiding research in the field to support the development of programs that prepare teachers to experience and promote success for every student in their initial years of practice is critical.

\section{Issues within Teacher Education Research}

External issues such as globalization, limited funding and increased accountability exist, however challenges are compounded in light of issues within teacher education research. The current call for the establishment of a common language, tools, and frameworks were noted laments throughout teacher education research (Boyd, Grossman, Lankford, Loeb, \& Wyckoff, 2009; Cochran-Smith \& Zeichner, 2004; Korthagen, 2004; Zeichner, 2005). Convoluted and confusing preparation vernacular limits cohesiveness across programs and may contribute to recognized empirical evidence gaps (Cochran-Smith \& Zeichner, 2005; Korthagen, 2004; Zeichner, 2005). Such gaps hinder the selection and development of effective teacher educator pedagogical practices.

Although we have learned some things about the impact of particular instructional approaches on teachers' knowledge and beliefs, there have been few systematic comparisons of the impact of different instructional methods and the effects of instructional methods on future teachers' practices. (Zeichner, 2005, p. 740)

Avalos (2011) concurred at the conclusion of a ten years literature review on preservice and inservice teacher professional development. Avalos recognized the complexity of "teachers learning, how to learn and transforming their knowledge into practice for the benefit of their students' growth" (p. 10). While several effective preparation strategies were identified and analyzed, Avalos ultimately acknowledged the limited understanding and evidence supporting effective instructional strategies to support sustainable teacher professional development.

Furthermore, Korthagen (2004) recognized a glaring gap of foundational knowledge guiding the development of teacher preparation practices. The pedagogy of effective instruction for children was built upon theoretical understandings gained from psychology and while there had been several developments within the scientific field, 
the developments have failed to transfer to or influence teacher education research and preparation (Korthagen, 2004). The need for informed teacher practitioners to guide research and assist in identifying best practices in pedagogy is essential but faces distinct challenges.

Compounding these tasks, Murray and Male (2005) found that teacher educators often maintained a strong commitment to their role as former classroom teachers and failed to transition to the research expectations of academia. Murray and Male reported that teacher educators who staked professional credibility on previous classroom experience and maintained a strong "ex-school teacher" identity, often held "ambivalent or negative" attitudes towards research (p. 127). This "deficit model" approach towards teacher education inhibited professional growth and reinforced a commonly held view of teacher educators as "semi-academics" by others in academia (p. 127). Murray and Male (2005) recommended the development of induction programs to assist teacher educators in developing an effective blend of educator pedagogy with research practices important to their work in preparing new teachers. Teacher educators moving into higher education with an interest in research and development of models to showcase effective strategies for teacher preparation deemed necessary supports to ensure successful transitions.

A 'deficit model' approach to research and limited theoretical or foundational research and a general lack of language cohesion promulgates the issues in effective program design for teacher preparation. Despite disparities, Korthagen, Loughran, and Russell (2006) argued that, "In this new century, teacher education is beginning to be recognized and valued as an object of academic research" (p. 1020). Recognizing the intricate relationship between teacher education research and designing highly effective models to prepare teachers for instructional methods critical to students in the $21^{\text {st }}$ century can begin to bridge the gap between theory and practice in today's classrooms.

\section{Conclusion}

Though teacher education programs have undergone criticism, researchers recognized the essential role programs play in equipping effective educators with the necessary knowledge and skills to embrace the requirements and rewards of today's classrooms. Identified in this article were external influences and internal issues that challenge teacher preparation and deter from meaningful education reform and the development of effective pedagogy. Identified limitations weaken teacher educator practice and the ability to prepare teacher candidates to meet the demands of $21^{\text {st }}$ century teaching. The literature provided an increase in awareness and defined need to support innovative practices, further research, and preparation of effective teacher candidates for each classroom. In addition, helping teacher practitioners transition into 
the role of researchers in a quest to define practical and trusted methods in educator practice will add to untangling the complex nature of teacher education preparation. Clear discussion of issues confronting candidates in the field and a deeper understanding of global and national issues remain important to today's classrooms. These advancements in teacher preparation programs will empower progress and address foundational components in preparing a new cadre of teachers equipped to embrace the innovations of teaching in the $21^{\text {st }}$ century.

\section{References}

Avalos, B. (2011). Teacher professional development in teaching and teacher education over ten years. Teaching and Teacher Education, 27, 10-20.

Book, C. L., \& Freeman, D. J. (1986). Differences in entry characteristics of elementary and secondary teacher candidates. Journal of Teacher Education, 37(2), 47-51.

Boyd, D., Grossman, P.L., Lankford, H., Loeb, S., \& Wyckoff, J. (2009). Teacher preparation and student achievement. Educational Evaluation and Policy Analysis, 31, 416-440.

Council for the Accreditation of Educator Preparation. (2013, August 29). CAEP

Council for the Accreditation of Educator Preparation. Retrieved October 5, 2013, from http://www.caepsite.org/standards.html

Cochran-Smith, M. (2003). Learning and unlearning: the education of teacher educators. Teaching and teacher education, 19, 5-28.

Cochran-Smith, M., \& Zeichner, K. M. (2005). Studying teacher education: The report of

the AERA Panel on Research and Teacher Education. Mahwah, N.J.: Lawrence Erlbaum Associates.

Cole, A. L., \& Knowles, J. G. (1993). Teacher development partnership research: A focus on methods and issues. American Educational Research Journal, 30, 473-495. Common Core State Standards Initiative | Home. (2010, January 1). 
Common Core State Standards Initiative | Home. Retrieved October 8, 2013, from Darling-Hammond, L., \& Bransford, J. (2005). Preparing teachers for a changing world what teachers should learn and be able to do. San Francisco, CA: Jossey-Bass.

Duncan, A. (2012, February 15). Teachers Get R-E-S-P-E-C-T. Remarks of Secretary Arne Duncan at a Teacher Town Hall. Retrieved from www.ed.gov.er.lib.k-state.edu/news/speeches/teachers-get-r-e-s-p-e-c-t

Fullan, M., \& Stiegelbauer, S. M. (2007). The new meaning of educational change $\left(^{\text {th }}\right.$ ed.). New York, NY: Teachers College Press.

Gollnick, D. M., \& Chinn, P. C. (2006). Multicultural education in a pluralistic society (7th ed.). Upper Saddle River, N.J.: Pearson/Merrill/Prentice Hall.

Hamilton, M. L., Pinnegar, S. (2001). On the threshold of a new century. Journal of Teacher Education, 51(3), 234.

Hollingsworth, S. (1989). Prior beliefs and cognitive change in learning to teach. American Educational Research Journal, 26, 160-169.

Klecka, C., Lin, E., Odell, S., Spalding, E., Wang, J. (2010). Understanding teacher education reform. Journal of Teacher Education, 6(21), 395-402

Korthagen, F. (2004). In search of the essence of a good teacher: Towards a more holistic approach in teacher education. Teaching \& Teacher Education: An International Journal of Research and Studies, 20(1), 77-97.

Korthagen, F., Loughran, J., Russell, T. (2006). Developing fundamental principles for teacher education programs and practices. Teaching and Teacher Education. 22, 1020-1041.

Marzano, R. J., \& Heflebower, T. (2012). Teaching \& assessing 21st century skills. Bloomington, IN: Marzano Research Laboratory.

Murray, J. \& Male, T. (2005). Becoming a teacher educator: evidence from the field. Teaching and Teacher Education, 21, 125-142. 
Next Generation Science Standards | Next Generation Science Standards. (2013) http://www.nextgenscience.org/next-generation-science-standards

No Child Left Behind Act of 2001. (2002, January 8). U.S. Department of Education. Retrieved October 8, 2013, from http://www2.ed.gov/policy/elsec/leg/esea02/index.html

Obama, B. (2009, March 10). Remarks of the President to the United States Hispanic Chamber of Commerce | The White House. The White House. Retrieved from http://www.whitehouse.gov/the_press_office/Remarks-of-thePresident-of-the-United-States-Hispanic-Chamber-of-Commerce

Reynolds, A., Ross, S. M., \& Rakow, J. H. (2002). Teacher retention, teaching effectiveness and professional preparation: a comparison of professional development school and non-professional development school graduates, Teaching and Teacher Education, 18(3), 289-303.

RESPECT_Program.PDF. (2012, February 13). RESPECT Program Proposal. From www.ed.gov/blog/wpcontent/uploads/2012/02/RESPECT_Program m.pdf

Sprinthall, N. A., Reiman, A. J., \& Theis-Sprinthall, L. (1996). Teachers' professional development. In J. Sikula (Ed.), Handbook for research in teacher education (2nd ed., pp.).

Wilson, S. (Ed.). (2009). Teacher quality: Education policy white paper. Washington, DC: National Academy of Education.

Zeichner, K. (2005). Becoming a teacher educator: A personal perspective. Teaching and Teacher Education, 21(2), 117-124.

Zeichner, K., and Tabachnick, B. (1981). Are the effects of university teacher education washed out by school experience? Journal of Teacher Education 32, 7-11.

Zhao, Y., (2010). Preparing globally competent teachers: A new imperative for teacher education. Journal of Teacher Education, 61(5), 422-431. 